\title{
Hooked on zebrafish: insights into development and cancer of endocrine tissues
}

\author{
Caitlin Bourque and Yariv Houvras
}

Departments of Surgery and Medicine, Weill Cornell Medical College and New York Presbyterian Hospital, 1300 York Avenue, New York, New York 10065, USA

(Correspondence should be addressed to Y Houvras; Email: yah9014@ med.cornell.edu)

\begin{abstract}
Zebrafish is emerging as a unique model organism for studying cancer genetics and biology. For several decades zebrafish have been used to study vertebrate development, where they have made important contributions to understanding the specification and differentiation programs in many tissues. Recently, zebrafish studies have led to important insights into thyroid development, and have been used to model endocrine cancer. Zebrafish possess a unique set of attributes that make them amenable to forward and reverse genetic approaches. Zebrafish embryos develop rapidly and can be used to study specific cell lineages or the effects of chemicals on pathways or tissue development. In this review, we highlight the structure and function of endocrine organs in zebrafish and outline the major achievements in modeling cancer. Our goal is to familiarize readers with the zebrafish as a genetic model system and propose opportunities for endocrine cancer research in zebrafish.
\end{abstract}

Endocrine-Related Cancer (2011) 18 R149-R164

\section{Introduction: endocrine tissues in zebrafish}

Zebrafish have most organs found in higher vertebrates, including endocrine tissues. Development in zebrafish proceeds rapidly, the embryos are translucent and can be studied using light microscopy, and tissue-specific markers can be used to study the temporal and spatial patterns of gene expression in normal and mutant embryos. The differentiation program of endocrine organs in zebrafish has been the subject of significant study. These studies have led to valuable insights into the genes and pathways that control the induction, specification, and differentiation of endocrine tissues. In many cases, these programs are conserved between zebrafish and higher vertebrates and provide opportunities for making connections between developmental pathways and neoplasia.

\section{Follicular derived thyroid cells}

Adult zebrafish possess thyroid follicles, which are distributed in connective tissue along the ventral aorta (Fig. 1). The zebrafish thyroid, like that of other teleosts, is not encapsulated by connective tissue. The developmental program specifying thyroid follicular cells is conserved in zebrafish (Wendl et al. 2002). Zebrafish possess two NK2 homeobox 1 (NKX2-1, also known as TTF1) homologs due to an ancient gene duplication event (Rohr \& Concha 2000). Only one of these, $n k x 2.1 a$ is expressed in precursor and mature thyroid cells. Knockdown of $n k x 2.1 a$ during zebrafish embryogenesis results in failure of thyroid development, similar to the effects observed after targeted disruption of Nkx2-1 in mouse (Elsalini et al. 2003).

Zebrafish embryos develop externally and development of major organs is complete by 5 days post fertilization. Studies from the Rohr laboratory have utilized these attributes to perform a detailed study of the spatial and temporal patterns of key thyroid markers during zebrafish embryogenesis (Alt et al. 2006). Expression of $n k x 2.1 a$, hematopoietically expressed homeobox (hhex), and paired box gene $2 \mathrm{a}$ (pax2a, also called pax2.1) can be identified in thyroid primordium at $\sim 24 \mathrm{~h}$ post fertilization (hpf). Expression of Tg mRNA begins at $\sim 30 \mathrm{hpf}$. The first thyroid follicles to bud from pharyngeal endoderm can 


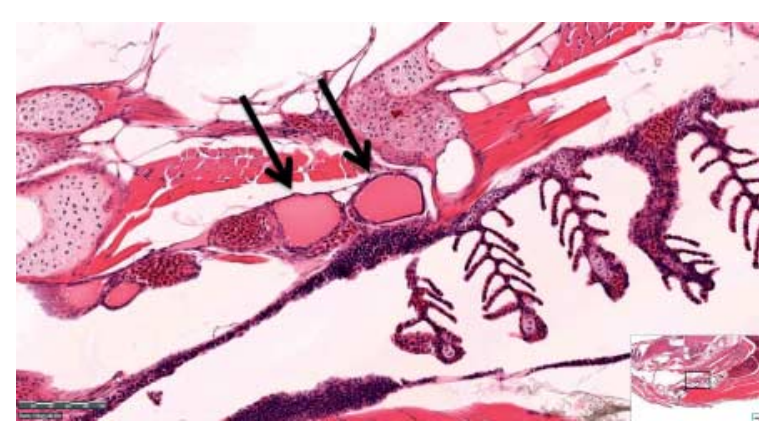

Figure 1 Adult zebrafish thyroid follicles. Sagittal section of a 12-month-old adult male zebrafish reveals thyroid follicles near the midline (arrows) in close association with the ventral aorta and gils. $20 \times$ magnification, scale is indicated (bottom left, $100 \mu \mathrm{m}$ ). The region of magnification is indicated by the black box in the inset (bottom right). Image available online at the Pennsylvania State University zebrafish atlas website (http:// zfatlas.psu.edu/view.php?s $=279 \& z=1 \& c=12486,13767)$.

be identified at $55 \mathrm{hpf}$. Mature zebrafish thyroid follicles express thyroglobulin protein, T4, and show uptake of radioactive iodine (Alt et al. 2006, Wendl et al. 2007). Zebrafish possess thyrotropes in the adenohypophysis that produce TSH. The developing zebrafish embryo relies on a maternal deposit of thyroid hormone in the yolk for the first 4-6 days of development. Treatment of developing zebrafish with the methimazole or phenylthiourea leads to the absence of T4 immunostaining in zebrafish embryos, and variable effects on other tissues (Elsalini \& Rohr 2003).

A genetic analysis of pathways involved in thyroid specification has revealed a conserved developmental program. The Rohr lab has investigated the effects of zebrafish pax 2a loss of function on thyroid development using a zebrafish mutant no isthmus (noi). Loss of pax2a in the noi mutants leads to loss of T4-positive follicles and loss of $n k x 2.1 a$ expression (Wendl et al. 2002). This is interesting since Pax2 has no apparent role in thyroid development in mouse, but is part of a paralogous group that includes Pax $2 / 5 / 8$, and Pax 8 plays a comparable role in mouse. Using zebrafish mutants with defects in the specification of endoderm it has been possible to establish that nodal signaling is required for thyroid development. Zebrafish mutants with defects in endoderm development such as oneeyed pinhead (oep) and cyclops (cyc) have significantly reduced or absent thyroid (Elsalini \& Rohr 2003). Fate-mapping studies using zebrafish blastula transplants have demonstrated that the zebrafish thyroid follicles are completely derived from endoderm (Alt et al. 2006). Studies of the zebrafish mutant hands off have revealed a non-cell autonomous role for the bHLH transcription factor heart and neural crest derivatives expressed 2 (hand2) and FGF signaling in thyroid fate specification (Wendl et al. 2007). Since the developmental program, tissue architecture, and function of thyroid are conserved in zebrafish, it is reasonable to assume that functionally relevant models of thyroid cancer can be constructed using the approaches outlined below.

\section{Calcitonin-producing cells: ultimobranchial body}

In humans, parafollicular C-cells are a neural crestderived lineage that secrete calcitonin. C-cells arise from the ultimobranchial bodies (UBB) that are derived from the fourth and fifth pair of branchial pouches during embryonic development (Biddinger \& Ray 1993). These cells migrate into the developing thyroid. In lower vertebrates such as birds and fish, the UBB does not fuse with thyroid and remains a separate organ. In zebrafish, the UBB is a bilateral structure, which expresses calcitonin and is found adjacent to the heart atrium (Alt et al. 2006). The developmental differences in C-cells between fish and humans create an opportunity for genetic experiments that target the UBB without interfering with the development or function of follicular thyroid cells. Malignant transformation of C-cells leads to medullary thyroid cancer in humans, so it would be interesting to determine if a similar disease phenotype emerges in a species where C-cells are not colocalized with thyroid epithelial cells. Such studies may shed light on the role of follicular thyroid cells as a niche for C-cells in higher vertebrates.

\section{Parathyroid}

Zebrafish express parathyroid hormone and possess the gene for calcium sensing receptor (casr), both of which are expressed in gill tissue (Okabe \& Graham 2004). Glial cells missing homolog 2 (Gcm2), a critical regulator of parathyroid development in mammals, is expressed in pharyngeal endoderm in zebrafish, as in mammals (Hogan et al. 2004). Knockdown of gcm 2 in zebrafish embryos leads to defects in formation of internal gill buds. These studies suggest that the gill buds of zebrafish may represent an evolutionary ancestor of the parathyroid gland in terrestrial species.

Parathyroid carcinoma and the hereditary syndrome of hyperparathyroidism-jaw tumor (HPT-JT) are associated with mutations in CDC73 (HRPT2, Parafibromin) (Carpten et al. 2002). CDC73 is part of a highly conserved complex that negatively regulates transcriptional elongation (Rozenblatt-Rosen et al. 2005). The tissue specific basis of $C D C 73$ functioning as a tumor suppressor in human parathyroid is not well understood. Intriguingly, the zebrafish ortholog of $C D C 73$ was identified in a genetic suppressor screen where it 
regulates blood development (Bai et al. 2010). The identification of a zebrafish $c d c 73$ mutant may be a valuable tool for creating a zebrafish model of parathyroid carcinoma.

\section{Adrenal}

In zebrafish, steroidogenic and chromaffin cells are found in the anterior portion of the kidney admixed with renal and hematopoietic cells, in a region referred to as the intrarenal or head kidney. Zebrafish produce cortisol in response to stress and production is stimulated by ACTH (Gallo \& Civinini 2003). Zebrafish possess a homolog of human SF1, fflb (also known as nr5ala, nuclear receptor subfamily 5) that stimulates the expression of the steroid biosynthesis enzymes cyp11a and $3 \beta$-hsb (Chai et al. 2003). Knockdown of fflb leads to impaired differentiation of intrarenal cells and cyp11a expression (Hsu et al. 2003). Using knockdown of the ACTH receptor ( $m c 2 r$, ACTH receptor), work from the Allolio laboratory has demonstrated that pituitary corticotrophs in zebrafish are responsible for the larval development of the intrarenal organogenesis (To et al. 2007). As is the case in mice, early development of the intrarenal organ in fish is independent of pituitary influence, but the animals become dependent on pituitary signals by early larval stages of development. Treatment of zebrafish embryos with dexamethasone leads to suppression of proopiomelanocortin in the anterior pituitary and decreased expression of steroidogenic genes in the intrarenal cells, indicating a conserved mechanism of negative feedback.

Adrenocortical carcinoma (ACC) remains a challenging clinical entity with a very poor prognosis for patients with advanced disease (Allolio \& Fassnacht 2006). The molecular basis of human ACC remains incompletely understood. Since the basic developmental pathways specifying steroidogenic, and specifically cortisol, producing cells are conserved between mammals and fish, it may be possible to model ACC in zebrafish. As is the case with other lineage-specific transcription factors, an increased dose of the SF1 (also known as NR5A1, nuclear receptor subfamily 5) gene appears correlated with the development of ACC in humans (Doghman et al. 2007). Canonical Wnt signaling has been shown to be required for adrenal development, which is interesting since somatic CTNNB1 ( $\beta$-catenin) mutations are found in ACC (Kim et al. 2008). These observations suggest that the developmental pathways which regulate steroidogenic producing cells may be appropriate starting points for zebrafish models of ACC, and may allow further connections between neoplasia and development to be pursued.

\section{Pancreas}

The pancreas is the most intensively studied and best understood endocrine organ in zebrafish (Tiso et al. 2009). Anatomically the adult zebrafish pancreas is found as a single islet with exocrine (acinar) cells surrounding a core of endocrine cells. Additional small clusters of endocrine cells can be found adjacent to the intestine. Unlike the mammalian pancreas, the zebrafish pancreas does not develop from an invagination of foregut endoderm, but forms directly from anterior endoderm (Ober et al. 2003). Pancreatic progenitor cells can be identified by $15 \mathrm{hpf}$ in the developing zebrafish embryo and are characterized by production of insulin, glucagon, somatostatin, ghrelin, and cells secreting pancreatic polypeptide. The molecular pathways that lead from endoderm induction to specification of pancreas cell identity have been studied in detail during zebrafish embryogenesis (reviewed in Tiso et al. (2009)). Knockdown of the zebrafish ortholog of pancreatic and duodenal homeobox 1 gene (PDXI), pdxl, leads to failure of pancreatic development in zebrafish as in mouse (Yee et al. 2001).

The combination of pancreatic specific markers and genetic approaches has led to a detailed understanding of pancreas development in zebrafish. Using a transgenic reporter line of zebrafish that express GFP under the control of the ela3I (elastase A) promoter, research from the Lin lab has studied the effects of retinoids on exocrine pancreas development (Jiang et al. 2008). Using pancreasspecific promoters it has been possible to create models of both exocrine and endocrine pancreatic tumors (Yang et al. 2004, Park et al. 2008). It is possible to envision chemical screens using zebrafish embryos to identify compounds capable of promoting $\beta$-cell differentiation, or compounds blocking early stages of transformation in tumor models. A detailed understanding of the molecular and genetic pathways that control pancreatic stem cell identity may lead to novel therapies for patients with diabetes, and new drugs and drug targets in tumors arising from the pancreas.

\section{Cancer models in zebrafish}

\section{Early origins of zebrafish cancer research}

The first experimental approaches to creating cancer in zebrafish were reported by Stanton in the mid-1960s (Stanton 1965). In these studies zebrafish treated with the carcinogen diethylnitrosamine (DENA) developed liver tumors. Several decades later, Spitsbergen et al. 
$(2000 a, b)$ conducted detailed studies of the effects of dose, route of administration, and age on zebrafish exposed to the carcinogens $N$-methyl- $N^{\prime}$ nitro- $N$-nitrosoguanidine (MNNG) and 7,12-dimethylbenz[a]anthracene (DMBA). Untreated zebrafish have a low rate of spontaneous neoplasia; $\sim 1 \%$ of zebrafish over the course of their lifetime will develop a tumor. Zebrafish exposed to either MNNG or DMBA exhibited a range of cancers arising from gill, liver, gastrointestinal tract, pancreas/kidney, and testis. Tumors of epithelial and mesenchymal origin were observed with both agents. Treatment of juvenile zebrafish with DMBA led to the development of cancer in $45-66 \%$ of animals at the most potent doses (Spitsbergen et al. 2000a). In contrast to MNNG where tumors arise predominantly in epidermal tissues, DMBA treatment is associated with epidermal and mesenchymal tumors. One case of follicular-derived thyroid cancer was observed with DMBA treatment, but none were observed with MNNG treatment. Interestingly, thyroid cancer has been reported at higher levels in other fish species treated with MNNG (Park et al. 1993). These and other chemical carcinogenesis studies demonstrate that chemical mutagens retain the ability to cause malignant transformation in zebrafish tissues.

\section{T-cell leukemia}

A pivotal study performed in the Look lab led to the creation of a T-cell leukemia model in zebrafish (Table 1; Langenau et al. 2003). Microinjection of a plasmid encoding the zebrafish recombination activating gene 2 (rag2) promoter, a lymphocyte-specific promoter, driving the expression of murine $c-M y c$ led to mosaic transgenic zebrafish with a clonal expansion of T-lymphocytes with hallmarks of leukemia. Fluorescently labeled leukemia cells were serially transplanted and homed to the thymus of immunosuppressed recipient zebrafish. To overcome the early lethality caused by c-Myc overexpression in thymocytes, the authors created a system in which microinjection of Cre RNA leads to recombination and activation of a floxed $c-M y c$ transgene (Langenau et al. 2005). In a related study, the authors were able to temporally control the activation of $c-M y c$ using a heat shock $70(h s p 70)$ promoter driving Cre recombinase (Feng et al. 2007). These creative approaches highlight the technical achievements possible in zebrafish and demonstrate that tissue-specific oncogenes from higher vertebrates retain the capacity to cause malignant transformation in zebrafish.

\section{Malignant melanoma}

Human melanoma is characterized by a high frequency of mutations in BRAF and NRAS, similar to papillary thyroid cancer. The most common mutation in human melanoma is $B R A F^{V 600 E}$, found in $\sim 40-50 \%$ of patients with melanoma. A zebrafish model of melanoma created in the Zon lab examined the role of $B R A F^{V 600 E}$ in nevi and melanoma formation in vivo (Patton et al. 2005). Expression of BRAF $F^{V 600 E}$ under the control of the melanocyte-specific promoter, microphthalmia-associated transcription factor (mitf), was sufficient to form nevi in zebrafish. Melanocytespecific expression of $B R A F^{V 600 E}$ on a p53 mutant background led to animals that developed melanoma with $100 \%$ incidence. Zebrafish melanomas were serially transplantable, displayed aneuploidy, and had activation of mitogen-activated protein kinase pathway. A fluorescently labeled $R A S^{Q 61 K}$ driven transgenic model of melanoma also relied on p53 loss of function for tumor formation (Dovey et al. 2009). Gene signature analysis of these tumors indicated that human melanoma tumorigenesis pathways are conserved in the zebrafish.

In the Zon lab, we utilized the $\mathrm{Tg}$ (mitf:BRAF $F^{\text {V600ENVOOE }}$ ); $p 53^{-1-}$ melanoma prone zebrafish to construct a genetic system capable of screening candidate genes for the ability to accelerate or slow melanoma formation (Fig. 2; Ceol et al. 2011). Candidate genes were selected from chromosome 1q21.2 based on the identification of a recurrently amplified genomic region in a set of 101 human metastatic melanoma short-term cultures. We filtered amplified genes to select candidates that were also overexpressed based on microarray data. To test candidates we developed a method of rescuing melanocytes in an mitf $^{-/}$(nacre) zebrafish. Zebrafish with a mutation in mitf lack melanocytes and are phenotypically albino. Microinjection of embryos from this strain with a vector containing an mitf minigene leads to mosaic 'rescue' of melanocytes. We built a specialized transposon vector, MiniCoopR, to rescue melanocytes and drive candidate gene expression. When we use MiniCoopR in a triple transgenic/mutant strain of zebrafish: Tg (mitf:$\left.B R A F^{V 600 E}\right) ; p 53^{-/-} ;$mitf $^{-1-}$ zebrafish, the rescued melanocytes are melanoma prone, because they express oncogenic $\mathrm{BRAF}^{\mathrm{V} 600 \mathrm{E}}$ and carry a $p 53$ lossof-function mutation. An advantage of this approach is that we are able to program rescued melanocytes to express any candidate gene product and study the effects on tumor onset. Using the MiniCoopR system we were able to create over 3000 transgenic fish to assay the ability of each candidate gene to 
Table 1 Zebrafish cancer models

\begin{tabular}{|c|c|c|c|c|c|}
\hline Histology & $\begin{array}{l}\text { Oncogene/tumor } \\
\text { suppressor }\end{array}$ & Promoter & Tissue & Notes & Reference \\
\hline \multicolumn{6}{|c|}{ Transgenic zebrafish cancer models } \\
\hline T-cell ALL & $c-M y c$ & rag2 & Lymphocytes & $\begin{array}{l}\text { Transplanted tumor cells homed to } \\
\text { the thymus of recipient zebrafish }\end{array}$ & $\begin{array}{l}\text { Langenau et al. } \\
\text { (2003) }\end{array}$ \\
\hline T-cell ALL & $\mathrm{NOTCH} 1$ & rag2 & Lymphocytes & Tumors developed at 5 months & Chen et al. (2007) \\
\hline B-cell ALL & $T E L-A M L 1$ & ef $1 \alpha^{a}$ & B-cells & $\begin{array}{l}\text { Leukemia developed with a ubiqui- } \\
\text { tous promoter }\end{array}$ & $\begin{array}{l}\text { Sabaawy et al. } \\
(2006)\end{array}$ \\
\hline AML & AML1-ETO & hsp70 & Myeloid cells & $\begin{array}{l}\text { AML1-ETO promotes progenitor cell } \\
\text { fate switch }\end{array}$ & Yeh et al. (2008) \\
\hline AML & MOZ-TIF2 & spi1 & Myeloid cells & $\begin{array}{l}\text { Leukemia arose in transgenic } \\
\text { zebrafish }\end{array}$ & $\begin{array}{l}\text { Zhuravleva et al. } \\
\text { (2008) }\end{array}$ \\
\hline Melanoma & $B R A F$ & mitf & Melanocytes & $\begin{array}{l}\text { BRAF is sufficient for nevi formation } \\
\text { but requires p53 loss of function to } \\
\text { form tumors }\end{array}$ & Patton et al. (2005) \\
\hline Melanoma & NRAS & mitf & Melanocytes & $\begin{array}{l}\text { Melanoma tumorigenesis pathways } \\
\text { are conserved in zebrafish }\end{array}$ & Dovey et al. (2009) \\
\hline Melanoma & HRAS & kit, mitf & Melanocytes & $\begin{array}{l}\text { Gal4-UAS system used to compare } \\
\text { mitf versus kit promoters }\end{array}$ & $\begin{array}{l}\text { Santoriello et al. } \\
\text { (2010) }\end{array}$ \\
\hline Melanoma & HRAS & mitf & Melanocytes & $\begin{array}{l}\text { PI3K-AKT signaling required for } \\
\text { melanoma progression }\end{array}$ & $\begin{array}{l}\text { Michailidou et al. } \\
\text { (2009) }\end{array}$ \\
\hline Pancreatic carcinoma & KRAS & ptf1 & $\begin{array}{l}\text { Exocrine } \\
\text { pancreas }\end{array}$ & $\begin{array}{l}\text { Tumors are invasive and demon- } \\
\text { strate upregulation of Hedgehog } \\
\text { signaling }\end{array}$ & Park et al. (2008) \\
\hline $\begin{array}{l}\text { Neuroendocrine } \\
\text { carcinoma }\end{array}$ & $M Y C N$ & myoD & Islet cells & $\begin{array}{l}\text { Tumors arose at } 4-6 \text { months and } \\
\text { expressed insulin }\end{array}$ & Yang et al. (2004) \\
\hline $\begin{array}{l}\text { Embryonal rhabdo- } \\
\text { myosarcoma }\end{array}$ & KRAS & rag2 & Satellite cell & $\begin{array}{l}\text { Conserved gene signature of RAS } \\
\text { pathway activation in ERMS }\end{array}$ & $\begin{array}{l}\text { Langenau et al. } \\
\quad(2007)\end{array}$ \\
\hline $\begin{array}{l}\text { Rhabdomyosarcoma, } \\
\text { MPD, MPNST }\end{array}$ & KRAS & $\beta$-actin & Muscle & $\begin{array}{l}\text { Conditionally induced activation of } \\
\text { floxed KRAS using heat shock }\end{array}$ & Le et al. (2007) \\
\hline Multiple $^{\mathrm{b}}$ & $\begin{array}{l}\text { smo and } \\
\text { myristylated- } \\
\mathrm{h} A K T\end{array}$ & $k r t 4$ & Glial cells & $\begin{array}{l}\text { Activation of Hedgehog and PI3K- } \\
\text { AKT pathways cooperated in } \\
\text { tumorigenesis }\end{array}$ & Ju et al. (2009) \\
\hline \multicolumn{6}{|c|}{ Zebrafish mutants with cancer predisposition } \\
\hline MPNST & tp53 & & Schwann cell? & $\begin{array}{l}28 \% \text { of mutant zebrafish developed } \\
\text { tumors }\end{array}$ & $\begin{array}{l}\text { Berghmans et al. } \\
\text { (2005) }\end{array}$ \\
\hline Ocular tumor & ptenb & & Eye & $\begin{array}{l}\text { ptenb has unique function in the } \\
\text { zebrafish eye }\end{array}$ & $\begin{array}{l}\text { Faucherre et al. } \\
\text { (2008) }\end{array}$ \\
\hline $\begin{array}{l}\text { Intestinal, pancreatic, } \\
\text { and hepatic adenomas }\end{array}$ & $a p c$ & & Several & $\begin{array}{l}\text { Accumulate } B \text {-catenin and express } \\
\text { Wnt target genes }\end{array}$ & $\begin{array}{l}\text { Haramis et al. } \\
\quad(2006)\end{array}$ \\
\hline Gonadal tumors & brca2 & & Gonad & $\begin{array}{l}\text { Mutants have defects in ovarian } \\
\text { and testis development }\end{array}$ & Shive et al. (2010) \\
\hline $\begin{array}{l}\text { Testicular germ cell } \\
\text { tumor }\end{array}$ & lamc1 & & Testis & $\begin{array}{l}\text { Tumors develop at median age of } \\
7 \text { months and are detectable by } \\
\text { micro-ultrasound }\end{array}$ & $\begin{array}{l}\text { Neumann et al. } \\
\text { (2009) }\end{array}$ \\
\hline MPNST & $r p$ & & Schwann cell? & $\begin{array}{l}\text { Impaired ability to translate p53 } \\
\text { protein }\end{array}$ & Lai et al. (2009) \\
\hline Neuroblastoma & fbxw4 & & $\begin{array}{l}\text { Cranial } \\
\text { ganglia }\end{array}$ & $\begin{array}{l}\text { Misregulation of neighboring gene, } \\
\text { fgf8, associated with tumor } \\
\text { development }\end{array}$ & $\begin{array}{l}\text { Amsterdam et al. } \\
\text { (2009) }\end{array}$ \\
\hline MPNST & emi1 & & Schwann cell? & $\begin{array}{l}\text { emi1 homozygotes show defects } \\
\text { in hematopoiesis and genome } \\
\text { instability }\end{array}$ & $\begin{array}{l}\text { Rhodes et al. } \\
\qquad(2009)\end{array}$ \\
\hline $\begin{array}{l}\text { MPNST, neurofi- } \\
\text { broma, others }\end{array}$ & $\begin{array}{l}\text { msh2, msh6, } \\
\quad \text { mlh1 }\end{array}$ & & Various & $\begin{array}{l}\text { Mutation in mismatch repair genes } \\
\text { lead to cancer in multiple tissues }\end{array}$ & $\begin{array}{l}\text { Feitsma et al. } \\
\qquad(2008)\end{array}$ \\
\hline
\end{tabular}

ERMS, embryonal rhabdomyosarcoma; MPNST, malignant peripheral nerve sheath tumor.

${ }^{\mathrm{a}}$ Xenopus laevis.

${ }^{\mathrm{b}}$ Glioblastoma, spindle cell sarcoma, rhabdomyosarcoma, ocular melanoma, astrocytoma, myxoma. 


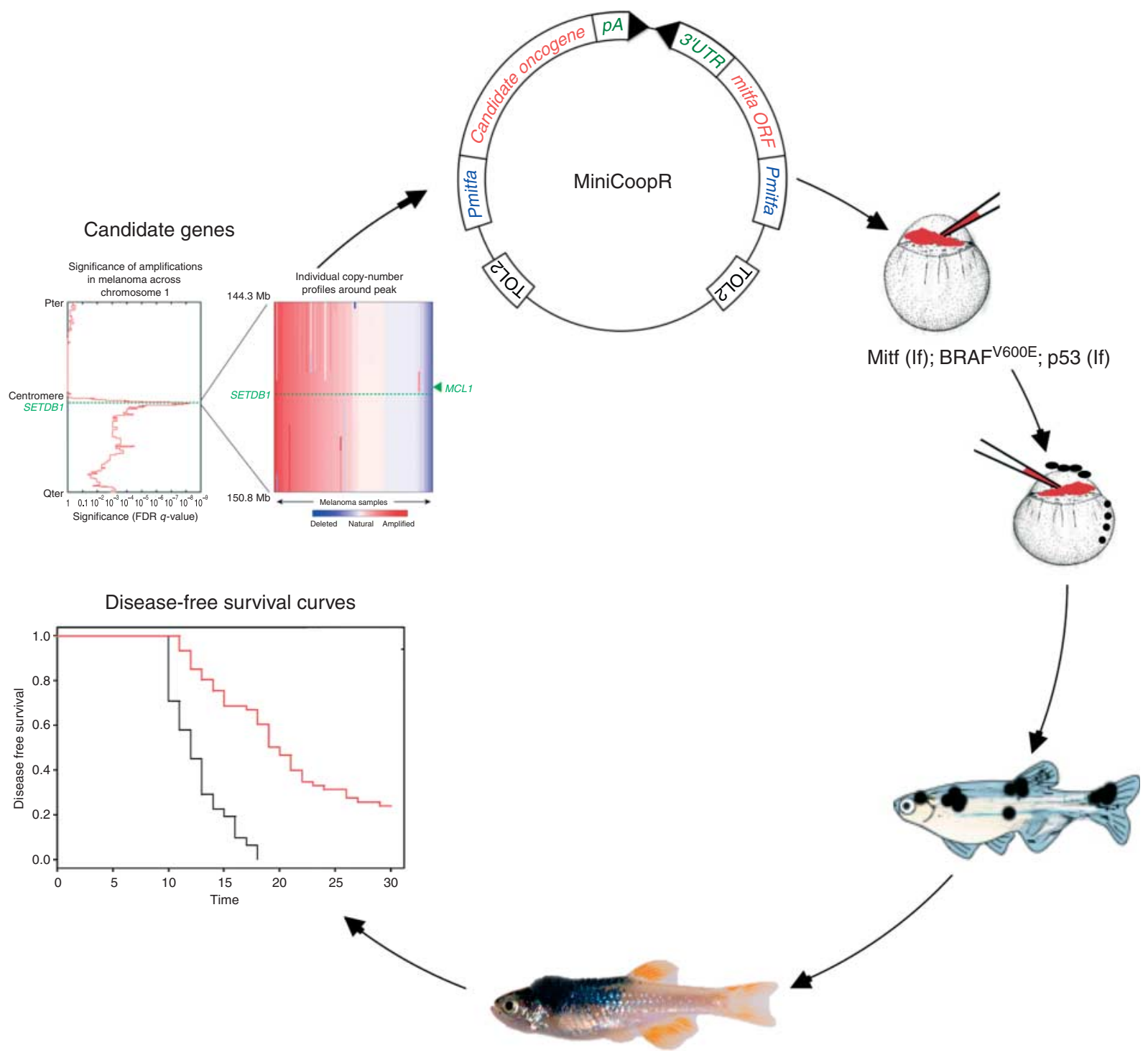

Figure 2 Overview of the zebrafish MiniCoopR screen. Candidate genes were identified from a genomic analysis of human patient samples. We focused on genomic regions that were recurrently amplified in metastatic melanoma to identify a region on chromosome 1q21 for further study. Candidate genes were individually cloned into MiniCoopR, a tol2 transposon-based vector. MiniCoopR vectors were microinjected into embryos from the indicated transgenic strain. Embryos with melanocyte rescue were identified at 2 days postinjection. Adult zebrafish with rescued meanocytes were followed for the development of melanoma, which is visible as a raised lesion. Disease-free survival was compared between each candidate gene and a reference control gene (GFP) to identify genes capable of accelerating or slowing the rate of melanoma formation.

accelerate or suppress tumor formation. This approach led to the identification of SET domain bifurcated 1 (SETDB1), a histone methyltransferase, as a cooperating oncogene in melanoma. Expression of SETDB1 accelerates the onset of melanomas, and cooperates with BRAF to alter the pigmentation pattern. SETDB1 overexpressing melanomas were highly invasive, bypassed a senescent arrest, and had genetic signature present in human melanomas. An analysis of human melanomas revealed that $\sim 70 \%$ of biopsies from patients with metastatic melanoma tested $(n=91)$ exhibit high levels of SETDB1 by immunohistochemistry. This study highlights how a genetic model in zebrafish can be adapted to functionally validate driver genes from candidates identified in genomic analyses.

The Mione lab has created a model of melanoma in zebrafish using the Gal4-UAS approach (Santoriello et al. 2010). With this system, researchers are able to test the effects of an oncogene under the control of 
different promoters. By crossing UAS-HRAS $S^{G 12 V}$ transgenic fish to a promoter-Gal4 transgenic fish, the expression of an oncogene can be studied under the control of different promoters. This approach was utilized to characterize the differences between the mitf versus kit (kit receptor a) promoters as they drive the expression of HRAS ${ }^{\mathrm{G} 12 \mathrm{~V}}$. They found that kit driven melanomas were more aggressive and developed earlier than mitf driven melanomas. Blastula transplantation was used to demonstrate that $H R A S^{G 12 V}$ transformed cells, driven from the kit promoter, proliferate and form melanomas cell autonomously.

The Hurlstone lab used $H R A S^{G 12 V}$ under the zebrafish melanocyte promoter, mitf, to dissect the mechanism of RAS pathway activation in melanoma (Michailidou et al. 2009). Expression of HRAS ${ }^{\mathrm{G} 12 \mathrm{~V}}$ under the control of the mitf promoter resulted in the development of melanoma in $90 \%$ of animals by 12 weeks. Coexpression of a dominant negative phosphoinositide 3-kinase (PI3K) regulatory domain mutant, $\Delta \mathrm{p} 85$, which interferes with interaction with the p110 catalytic domain (PIK3CA), resulted in dramatic suppression of RAS ${ }^{\mathrm{G} 12 \mathrm{~V}}$ induced melanoma in assays of mosaic juveniles at 12 weeks and in stable transgenic lines. Melanomas arising in the $\operatorname{HRAS}^{\mathrm{G} 12 \mathrm{~V}}: \Delta \mathrm{p} 85$ animals were less invasive and showed reduced levels of phospho-Akt. These studies demonstrate that PI3K signaling plays a role in HRAS $^{\mathrm{G} 12 \mathrm{~V}}$ induced malignant transformation of melanocytes in the zebrafish model system.

\section{Myeloid leukemia}

Acute myeloid leukemia (AML) has several molecularly defined subsets. One subset of AML is defined by the presence of translocation $t(8 ; 21)$ which fuses the runt-related transcription factor $1(R U N X 1$, also known as $A M L$ ) and ETO (also known as RUNX1TI, runtrelated transcription factor 1 ; translocated to, 1) genes. Several studies have addressed the genetic basis of $t(8 ; 21)$ leukemia using zebrafish. The Crosier lab performed a detailed analysis of zebrafish runxl, which they demonstrated is required for blood formation in fish, as in mouse (Kalev-Zylinska et al. 2002). Overexpression of human AML-ETO in zebrafish led to defects in hematopoiesis and vascular development, which mimic the effects observed in a comparable mouse models. Yeh et al. (2008) developed a heatshock inducible $A M L$-ETO transgenic line of zebrafish. In this temporally inducible system, expression of AML1-ETO in zebrafish embryos disrupts the differentiation of hematopoietic progenitor cells by promoting a fate switch from erythroid to myeloid lineages.
Treatment of AML1-ETO expressing zebrafish embryos with trichostatin $\mathrm{A}$, an inhibitor of histone deacetylases, reversed the differentiation block (Yeh et al. 2009). They performed a chemical screen to identify compounds able to suppress oncogenic effects of AML1-ETO, and a cyclooxygenase 2 (Cox2) inhibitor was identified. In a study by Dayyani et al. (2008) the authors use zebrafish embryos to test the ability of gro3, a Groucho/transducin-like enhancer of split (TLE) homolog, to cooperate with AML-ETO in deregulating hematopoiesis. Groucho/TLE proteins are corepressors involved in multiple aspects of gene regulation and development. The authors perform morpholino knockdown of gro3 in zebrafish after induction of AML-ETO expression and demonstrate that the combination leads to an absence of circulating blood cells and the presence of blast-like cells that express granulocytic markers. These studies highlight functional insights into the effects of the AML-ETO oncoprotein on hematopoiesis obtained through zebrafish studies.

\section{Other leukemia models}

Several other zebrafish models of leukemia have been generated (Zhuravleva et al. 2008). TEL-JAK2 (TEL is also known as ETV6, Ets variant 6) translocation results in constitutive activation of the Janus kinase 2 (JAK2) kinase and is found in lymphoblastic and myeloid leukemia. Mosaic zebrafish embryos expressing the zebrafish tel-jak2 fusion protein in myeloid cells displayed a block in differentiation of the myeloid and erythroid lineages (Onnebo et al. 2005). A stable transgenic zebrafish model was used to explore the cell of origin involved in TEL-AML1 induced pre-B ALL. Leukemia arose only in the transgenic zebrafish expressing the TEL-AML1 ubiquitously, but not when specifically expressed in lymphoid progenitors (Sabaawy et al. 2006). NOTCH1 is commonly mutated in T-cell acute lymphoblastic leukemia (T-ALL). In mosaic zebrafish expressing fluorescently labeled activated NOTCH1 under the lymphocyte rag2 promoter, malignant disease developed at 5 months (Chen et al. 2007). NOTCH activation cooperated with B-cell CLL/lymphoma 2 ( $b c l 2$ ) overexpression in stable transgenic lines, establishing a genetic interaction in this model of T-ALL.

\section{Pancreatic cancer}

Several labs have utilized zebrafish to model pancreatic cancers and explore early pancreas development. In one study, investigators from the Leach lab studied the effects of KRAS ${ }^{\mathrm{G} 12 \mathrm{~V}}$ expression on pancreas 
development (Park et al. 2008). By directly observing pancreatic progenitor cells during development, they were able to demonstrate that KRAS ${ }^{\mathrm{G} 12 \mathrm{~V}}$ expression induces a block in differentiation of exocrine progenitors. In this model, pancreatic cancers arising in zebrafish are invasive, have cytologic characteristics of human adenocarcinoma, and show evidence of upregulation of Hedgehog signaling. In a study from the Look lab, pancreatic neuroendocrine tumors developed in mosaic transgenic zebrafish selectively expressing MYCN (Yang et al. 2004). These tumors were locally invasive and normal appearing exocrine cells and ducts were observed in the tumors. These tumors expressed synaptophysin and insulin suggesting islet cells of the pancreas as the cell of origin. An $N$-ethyl- $N$-nitrosourea (ENU) based screen for mutants in exocrine pancreas development identified a mutant in $\operatorname{trpm} 7$, a cation channel with protein kinase activity. Transient receptor potential cation channel, subfamily $\mathrm{m}$, member 7 (TRPM7) is overexpressed in human exocrine pancreatic cancer, revealing a potential link between developmental regulators and neoplasia (Yee et al. 2011).

\section{Rhabdomyosarcoma}

Expression of oncogenic KRAS ${ }^{\mathrm{G} 12 \mathrm{D}}$ was sufficient to cause embryonal rhabdomyosarcoma (ERMS) in studies from the Zon laboratory (Langenau et al. 2007). Surprisingly, these tumors arose in animals where KRAS was driven from rag2 regulatory sequences. The authors demonstrate that the zebrafish rag 2 regulatory sequences drive expression in satellite cells of muscle in addition to lymphocytes. Injection of rag2$K R A S^{G 12 D}$ led to highly penetrant and early onset rhabdomyosarcoma tumors in zebrafish. Gene signature analysis of zebrafish and human ERMS indicated a conserved signature of RAS pathway activation in rhabdomyosarcoma. By co-injecting fluorescent reporters driven from different promoters, subpopulations of cells were differentially labeled within zebrafish rhabdomyosarcoma and their self-renewal capabilities were compared in transplantation studies. These studies suggest that the satellite cell may be the cell of origin in rhabdomyosarcoma.

\section{Other transgenic models}

Several labs have used promoters with widespread tissue activity to drive the expression of oncogenes in zebrafish. In one approach, heat shock was used to activate Cre recombinase and cause recombination and activation of a $\beta$-actin:KRAS $S^{G 12 D}$ allele (Le et al. 2007). This led to four types of tumors/hyperplasia including rhabdomyosarcoma, myeloproliferative disorder (MPD), intestinal hyperplasia, and malignant peripheral nerve sheath tumors (MPNST). Heat shock was also able to induce activation of KRAS ex vivo and induce MPD in recipient zebrafish. In studies from the Chen laboratory, a constitutively activated zebrafish smoothened (smo) was expressed using a keratin promoter in the Gal4 system with an activated $A K T$ (Ju et al. 2009). Multiple tumor types including spindle cell sarcoma, glioblastoma, and astrocytoma resulted from this approach.

\section{Techniques}

\section{Clonal zebrafish}

A method for generating clonal (isogenic) zebrafish using gynogenetic female homozygous fish as founders has been described (Streisinger et al. 1981). In the first step of this method u.v. inactivated sperm are used to fertilize zebrafish eggs. The sperm are capable of activating the embryos but the u.v. damage prevents them from making a genetic contribution, so the resulting organism is haploid. If heat shock or pressure is applied shortly after fertilization the first cleavage division can be prevented, creating a diploid homozygous fish. This fish is raised to adulthood and the procedure is repeated. In the second round, the animals arising from each female are genetic clones of each other. This method has been used to improve upon transplantation studies in zebrafish. Previous transplant experiments required recipient fish to be sublethally irradiated before transplantation to promote immunosuppression and prevent graft rejection (Langenau et al. 2003), clonal zebrafish were used to demonstrate that carcinogen-induced hepatobiliary and pancreatic tumors could be serially transplanted into clonal animals without immune suppression (Mizgireuv \& Revskoy 2006).

To uncover the self-renewal potential in $c-M y c$ driven T-cell leukemia, work from the Langenau lab utilized clonal zebrafish (Smith et al. 2010). These studies assessed tumor initiating potential of leukemia by performing single-cell transplantations, and developed novel methods of screening adult recipient animals engrafted with fluorescent tumor cells. In a related study, the Revskoy lab serially transplanted T-ALL into syngeneic zebrafish (Mizgirev \& Revskoy 2010). These leukemia-bearing animals demonstrated sensitivity to known chemotherapeutics, establishing a model system for screening potential anticancer compounds in vivo. These studies have established clonal zebrafish as unique system for transplantation 
assays and provide opportunities to study engraftment, drug sensitivity, and to test the cancer stem cell hypothesis.

\section{Reverse genetics and tumor suppressors}

In zebrafish, ENU mutagenesis has been the foundation of a reverse genetic approach to generate mutations in specific genes. First, described in zebrafish by Wienholds et al. (2002), targeting induced local lesions in genomes (TILLING) uses ENU mutagenized male zebrafish bred with wild-type females. Sperm from the resulting $\mathrm{F}_{1}$ males is cryopreserved and genomic DNA analyzed for mutation in gene(s) of interest by DNA sequencing. Once a mutation has been identified, the cryopreserved sperm can be thawed and IVF is performed to generate an $\mathrm{F}_{2}$ generation. Berghmans et al. (2005) utilized TILLING to identify a point mutation in the DNA-binding domain of zebrafish $p 53$, M214K, which was shown to be a loss-of-function mutation. The $p 53^{M 214 K}$ zebrafish fail to undergo apoptosis after exposure to ionizing radiation, and develops MPNST, a type of sarcoma. The $p 53^{M 214 K}$ zebrafish has been a valuable resource for creating genetically engineered tumor models and for uncovering suppressors of apoptosis (Patton et al. 2005, Sidi et al. 2008).

Zebrafish harbor two orthologs of the tumor suppressor phosphatase and tensin homolog (PTEN), ptena and ptenb (Croushore et al. 2005). TILLING was used to identify ptena and ptenb mutant zebrafish lines, which have redundant roles in embryonic development, but distinct tumorigenic functions (Faucherre et al. 2008). Intriguingly, ptenb mutant zebrafish developed ocular tumors in the presence of normal ptena function. Gene duplications are relatively common in the zebrafish genome and often lead to tissue-specific functions. Studies from the laboratory of den Hertog demonstrated that PI3K inhibition with a small molecule, LY294002, suppresses the hyperplastic-dysplastic changes in eyes, heart, and brain observed in ptena ${ }^{-/-} ;$ptenb ${ }^{-/-}$embryos. These studies suggest that one could perform a chemical screen for chemical suppressors of the ptena $^{-/-}$; pten $b^{-/-}$phenotype which could lead to the discovery of novel PI3K inhibitors, such compounds would potentially have therapeutic utility in PTEN mutant tumors.

TILLING has been used to identify a mutation in the zebrafish homolog of adenomatous polyposis coli (APC; Hurlstone et al. 2003). Characterization of $a p c^{M C R}$ mutant zebrafish led to the characterization of $a p c$ as a tumor suppressor in zebrafish (Haramis et al. 2006). Heterozygous $a p c^{M C R}$ zebrafish developed tumors of the digestive tract spontaneously, primarily in liver and intestine. Tumor incidence was accelerated with the addition of DMBA. These tumors demonstrated upregulation of the $W n t / \beta$-catenin signaling pathway. Further studies of $a p c$ mutant zebrafish have demonstrated a novel role for Wnt/B-catenin signaling in liver regeneration after hepatectomy (Goessling et al. 2008).

Hereditary mutations in breast cancer 2 (BRCA2, early onset) are associated with increased risk of ovarian and breast cancer. TILLING has been used to isolate a missense mutation in the zebrafish brca2 ortholog (Shive et al. 2010). Brca2 $2^{Q 658 X}$ homozygous mutant zebrafish fail to undergo ovarian development and exhibit abnormal spermatogenesis. Examination of brca2 ${ }^{Q 658 X} ; p 53^{-/-}$adults revealed an increased incidence of testicular neoplasia. These studies reveal a role for brca2 in ovarian development and tumor formation in zebrafish. TILLING has also been used to generate several mutations in mismatch repair genes and study the effects on tumor development (Feitsma et al. 2008).

\section{Zinc finger nucleases}

Zinc finger nucleases (ZFN) are chimeric fusions between $\mathrm{C} 2 \mathrm{H} 2$ zinc fingers and the Fok I endonuclease that are selected for high-affinity binding to specific genomic loci. Dimerization of two zinc fingers at a locus leads to endonuclease dimerization and the generation of a double-stranded DNA break (Porteus \& Carroll 2005). Because DNA strand breaks are imperfectly repaired by non-homologous end joining, small insertions or deletions are formed. ZFN have been successfully used to generate loss-of-function alleles in plants, invertebrate organisms, cell lines, and zebrafish (Doyon et al. 2008). The Wolfe and Lawson labs have demonstrated the efficacy of using ZFN in zebrafish to selectively induce mutations at specific zebrafish genomic loci (Meng et al. 2008). Using the target locus $k d r$ (also known as $k d r l$, kinase insert domain receptor like), a receptor tyrosine kinase involved in vascular development, they created mutations with high efficiency, specificity, and germline transmission. Founder heterozygous zebrafish were morphologically normal and mutations were identified by PCR and complementation studies with a known mutant. Oligomerized pool engineering (OPEN) is an alternative method of creating ZFN with streamlined library screening (Maeder et al. 2008). This method has been used to efficiently design ZFN to target specific zebrafish genomic loci 
(Foley et al. 2009). Using in silico analysis, the authors estimate that $86 \%$ of transcripts in the zebrafish genome can be targeted using OPEN. These studies suggest that ZFNs are becoming a powerful method for performing site-selected mutagenesis in zebrafish.

\section{Forward genetic screens}

Forward genetic screens in zebrafish have had a major impact on developmental biology (Driever et al. 1996, Haffter \& Nusslein-Volhard 1996, Haffter et al. 1996). Several labs have performed screens in zebrafish to uncover cancer-related genes. Work from the Zon lab utilized phosphorylated histone $\mathrm{H} 3$ staining, a marker of proliferation, in a cell cycle screen to identify cancer prone mutants (Shepard et al. 2005, 2007, Neumann et al. 2009). These studies identified a zebrafish mutant of separase (also known as espll, extra spindle poles like 1), an anaphase promoting cysteine protease (Shepard et al. 2007). Heterozygous espll mutants were more susceptible to epithelial tumors after exposure to the chemical carcinogen MNNG. A lossof-function mutant of mybl2, the zebrafish $M Y B L 2$ $(B-M Y B)$ ortholog, was also identified (Shepard et al. 2005). These mutant zebrafish exhibited genome instability and increased cancer susceptibility. The cell cycle screen also identified a zebrafish model of germ cell tumors (Neumann et al. 2009). Zebrafish harboring a mutation in laminin, $\gamma 1$ (lamcl) exhibited, both spontaneous and carcinogen-induced, germ cell tumors. Micro-ultrasound, a useful tool for imaging zebrafish (Goessling et al. 2007), was utilized to detect subclinical germ cell tumors in $l a m c l^{\text {cz61 }}$ mutants. These studies demonstrate the ability of forward genetic screens in zebrafish to uncover novel genes involved in cancer.

\section{Insertional mutagenesis}

The Hopkins lab performed a large-scale insertional mutagenesis screen to identify genes essential for early embryonic development (Amsterdam et al. 1999). Blastula stage zebrafish embryos were injected with a retrovirus to produce loss-of-function alleles. The F3 progeny were screened for recessive mutants and 500 unique zebrafish lines representing insertions in $\sim 370$ genes were identified. This study provides an unparalleled collection of mutants in genes required for early vertebrate development. Many developmental genes have important links to cancer and endocrine disorders. For example, they isolated a mutant, hi548, which disrupts expression of vhnfl (also known as hnflba, HNF1 homeobox Ba), a transcription factor linked to kidney abnormalities and maturity onset diabetes in humans (Golling et al. 2002). A study of the hi2648 mutant, which disrupts expression of emil (also known as fbxo5, F-box protein 5), leads to hematopoietic defects and genome instability, and accelerated tumor formation on a p53 mutant background (Rhodes et al. 2009). Intriguingly, the Hopkins group noticed that $17 / 28$ zebrafish lines with mutations in ribosomal proteins have a tendency to develop highly aneuploid MPNST sarcomas. This suggests that alterations in protein translation may lead to a predisposition to the develop cancer and that zebrafish may be used to model genome instability in cancer (Lai et al. 2009, Zhang et al. 2010). A detailed study of tumor susceptibility in this collection revealed a neuroblastoma-like tumor in four dominant F-box and WD domain protein $4(f b x w 4)$ mutant alleles, all of which appeared to upregulate the neighboring $f g f 8$ (also known as $f g f 8 a$, fibroblast growth factor 8a) gene (Amsterdam et al. 2009).

\section{Xenotransplantation}

Several groups have demonstrated that human melanoma cells can be transplanted into zebrafish larvae where they proliferate and migrate (Lee et al. 2005, Haldi et al. 2006). Human tumor xenografts induce angiogenesis in zebrafish embryos that can be visualized using transgenic fish that express GFP in blood vessels (Nicoli \& Presta 2007, Nicoli et al. 2007). Studies from the Klemke lab have utilized confocal microscopy to quantify extravasation of metastatic cells and explore the genetics of vascular remodeling (Stoletov et al. 2007, 2010).

Studies from the Hendrix lab have proposed using the zebrafish embryo as a biosensor for the microenvironment of tumor cells (Lee et al. 2005). They have demonstrated that human melanoma cells survive after transplantation into blastula stage zebrafish embryos. Transplanted melanoma cells maintain a dedifferentiated state and co-express mesenchymal and epithelial cell markers. They identified a melanoma cell line capable of inducing aberrant axis development in the zebrafish embryo after transplantation, similar to the effects observed when nodal, a developmental morphogen, is ectopically expressed (Topczewska et al. 2006). Inhibition of nodal blocks the ability of the melanoma cells to induce an ectopic axis and causes the melanoma cells to become pigmented, suggesting a more differentiated state. By using the phenotype induced in a zebrafish embryo the authors are able to uncover a signaling pathway active in the tumor cells. 


\section{Metastatic models}

Several groups have developed models of metastasis using xenotransplantation in zebrafish embryos. The Cao lab has developed a novel method of inducing hypoxia in zebrafish (Cao et al. 2010, Rouhi et al. 2010). Hypoxia induces dissemination of transplanted mouse fibrosarcoma cells in zebrafish embryos and neo-angiogenesis in the tumor. Increasing the level of VEGF in the transplanted tumor cells also promotes invasion and dissemination of tumor cells in the zebrafish assay (Lee et al. 2009). The authors show that treatment of zebrafish embryos with sunitinib, a tyrosine kinase inhibitor of VEGFR2 (also known as $\mathrm{KDR}$, kinase insert domain receptor), or morpholino knockdown of vegfr2, results in decreased tumor invasion and dissemination. In a report from the Bagowski lab, both human cancer cell lines and primary tumors were shown to enter the circulation and colonize distant sites after transplantation into zebrafish embryos (Marques et al. 2009). By mating together two pigment mutants (roy and nacre) a transparent zebrafish, casper, was created and used to study transplantation (White et al. 2008). Using casper it is possible to visualize GFP-labeled hematopoietic stem cells (HSC) homing to the kidney marrow in adult recipients, and follow the migration of melanoma cells after transplantation. These emerging models may lead to novel chemical and genetic screens to identify suppressors of angiogenesis and metastasis.

\section{Chemical genetic screens}

Zebrafish embryos can be used in chemical screens in which hundreds or thousands of compounds are tested for the ability to induce a specific phenotype. Such phenotypes can include expression of a particular gene or suppression of a genetic defect. Phenotype-based screens have the advantage that the chemical hits can occur on any pathway that leads to the desired outcome. In a screen from the MacRae lab, 100 drugs in clinical use were tested for the ability to induce bradycardia in zebrafish embryos (Milan et al. 2003). Remarkably, 22/23 drugs known to cause QTc prolongation and bradycardia in humans, also caused bradycardia in zebrafish. The assay in zebrafish embryos was also capable of identifying drug-drug interactions that result from metabolism, a unique advantage of screening in the whole organism.

Zebrafish mutants may have complex phenotypes in specific tissues or organs. A mutation in the hairy/enhancer-of-split related with YRPW motif 2 (hey2) gene, a transcriptional repressor, leads to aortic coarctation (Weinstein et al. 1995). The Peterson lab performed a chemical suppressor screen to identify compounds capable of reversing this phenotype (Peterson et al. 2004). They identified two compounds that reversed the cardiovascular effects observed in the hey 2 mutant zebrafish. One compound, GS4012, induces vegf, which is effective in reversing this phenotype as well. These experiments demonstrate that a chemical screen in embryos can result in the discovery of drugs that suppress complex phenotypes. This approach to discovery is unbiased and it is independent of understanding the precise molecular mechanism of the mutant.

In zebrafish, the lateral line is a mechanosensory organ, which consists of hair cells organized into clusters known as neuromasts (Dambly-Chaudiere et al. 2003). The sensory hair cells in the inner ear of humans have functional similarities to the zebrafish lateral line hair cells. Hair cell injury and death within the inner ear is a major cause of hearing loss. In an innovative set of experiments, the Raible lab performed chemical and genetic suppressor screens to identify drugs and genetic pathways capable of conferring protection from aminoglycoside-induced hair cell death (Owens et al. 2008). In the chemical screen, zebrafish embryos were pre-treated with library of 10960 compounds, and then subjected to treatment with neomycin. They identified two compounds, both benzothiophene carboxamides, which were capable of blocking neomycin-induced hair cell death, without interfering with neomycin's antibiotic activity. The active compounds were also capable of protecting against neomycin-induced cell death in murine utricle cells in vitro. The authors performed an F3 genetic screen to identify genetic modifiers of neomycininduced hair cell toxicity. They identified several mutants, one of which, sentinel ( $c c 2 d 2 a$, coiled-coil and $\mathrm{C} 2$ domain containing $2 \mathrm{a}$ ), is protective against neomycin-induced hair cell death but not against cell death caused by cisplatin. Starting from a phenotype that has relevance in medicine these studies in zebrafish uncover novel drugs and genes, which may lead to new treatments for drug-induced ototoxicity.

North et al. (2007) performed a small molecule screen to identify chemicals capable of inducing or repressing HSC formation in the zebrafish embryo. Remarkably, they found that prostaglandin $\mathrm{E}_{2}\left(\mathrm{PGE}_{2}\right)$ increased HSC formation and $\mathrm{PGE}_{2}$ antagonists, such as celecoxib, decreased $\mathrm{HSC}$ formation. $\mathrm{PGE}_{2}$ also increased HSC formation in murine stem cell assays. This study led to a phase I clinical trial in which cord 
blood stem cells are treated ex vivo with $\mathrm{PGE}_{2}$ in an effort to expand HSCs before transplantation (Lord et al. 2007). This is the first example of a discovery in zebrafish that led directly to a clinical trial in human subjects.

In a recent study from the Zon lab, White et al. (2011) performed a chemical screen to identify drugs that can suppress cells of neural crest lineage. They found that leflunomide, an FDA approved drug for treatment of rheumatoid arthritis, inhibited multiple neural crest derivatives including melanocytes from the developing embryo. Treatment of melanoma xenografts with a combination of PLX4720 (a $B R A F^{V 600 E}$ inhibitor) and leflunomide led to greater growth inhibition than treatment with either drug alone, and in $40 \%$ of animals it led to near complete tumor regression. By focusing on the embryonic lineage of melanocytes and using zebrafish embryos to discover lineage specific chemical inhibitors, White et al. (2011) uncovered an inhibitor of melanoma. Leflunomide may have therapeutic utility in other cancers arising from the neural crest such as pheochromocytoma and medullary thyroid cancer.

\section{Conclusion}

The combination of chemical and genetic approaches in zebrafish can uncover specific drug-gene effects, which have medical relevance. There are many creative ways to design genetic and chemical screens in zebrafish by utilizing existing mutants or markers of specific cell types. Chemical screens performed in zebrafish embryos have the advantage of studying the effects of compounds in the whole animal. In these screens, the outcome of treatment can therefore be due to interactions between tissues, which would be absent in screens performed on homogenous cell populations. Chemical screens in zebrafish are informationally rich, and the hits are often reproducible when tested in higher vertebrates. We see potential for chemical screens in zebrafish to address specific problems relevant to endocrine oncology. Zebrafish embryos could be used to screen for compounds capable of modulating iodine uptake, increasing the specification of pancreatic $\beta$-cells, or ablating cells that express particular oncogenes relevant in endocrine cancers.

\section{Declaration of interest}

The authors declare that there is no conflict of interest that could be perceived as prejudicing the impartiality of the review reported.

\section{Funding}

This work was supported by a grant from the National Institutes of Health (Y Houvras K08DK075432).

\section{References}

Allolio B \& Fassnacht M 2006 Clinical review: adrenocortical carcinoma: clinical update. Journal of Clinical Endocrinology and Metabolism 91 2027-2037. (doi:10. 1210/jc.2005-2639)

Alt B, Reibe S, Feitosa NM, Elsalini OA, Wendl T \& Rohr KB 2006 Analysis of origin and growth of the thyroid gland in zebrafish. Developmental Dynamics 235 1872-1883. (doi:10.1002/dvdy.20831)

Amsterdam A, Burgess S, Golling G, Chen W, Sun Z, Townsend K, Farrington S, Haldi M \& Hopkins N 1999 A large-scale insertional mutagenesis screen in zebrafish. Genes and Development 13 2713-2724. (doi:10.1101/ gad.13.20.2713)

Amsterdam A, Lai K, Komisarczuk AZ, Becker TS, Bronson RT, Hopkins N \& Lees JA 2009 Zebrafish Hagoromo mutants up-regulate fgf8 postembryonically and develop neuroblastoma. Molecular Cancer Research 7 841-850. (doi:10.1158/1541-7786.MCR-08-0555)

Bai X, Kim J, Yang Z, Jurynec MJ, Akie TE, Lee J, LeBlanc J, Sessa A, Jiang H, DiBiase A et al. 2010 TIF1gamma controls erythroid cell fate by regulating transcription elongation. Cell 142 133-143. (doi:10.1016/j.cell.2010. 05.028)

Berghmans S, Murphey RD, Wienholds E, Neuberg D, Kutok JL, Fletcher CD, Morris JP, Liu TX, Schulte-Merker S, Kanki JP et al. 2005 tp53 mutant zebrafish develop malignant peripheral nerve sheath tumors. PNAS $\mathbf{1 0 2}$ 407-412. (doi:10.1073/pnas.0406252102)

Biddinger PW \& Ray M 1993 Distribution of C cells in the normal and diseased thyroid gland. Pathology Annual 28 205-229.

Cao Z, Jensen LD, Rouhi P, Hosaka K, Lanne T, Steffensen JF, Wahlberg E \& Cao Y 2010 Hypoxia-induced retinopathy model in adult zebrafish. Nature Protocols 5 1903-1910. (doi:10.1038/nprot.2010.149)

Carpten JD, Robbins CM, Villablanca A, Forsberg L, Presciuttini S, Bailey-Wilson J, Simonds WF, Gillanders EM, Kennedy AM, Chen JD et al. 2002 HRPT2, encoding parafibromin, is mutated in hyperparathyroidism-jaw tumor syndrome. Nature Genetics 32 676-680. (doi:10. 1038/ng1048)

Ceol CJ, Houvras Y, Jane-Valbuena J, Bilodeau S, Orlando DA, Battisti V, Fritsch L, Lin WM, Hollmann TJ, Ferre F et al. 2011 The histone methyltransferase SETDB1 is recurrently amplified in melanoma and accelerates its onset. Nature 471 513-517. (doi:10.1038/nature09806)

Chai C, Liu YW \& Chan WK 2003 Ff1b is required for the development of steroidogenic component of the zebrafish interrenal organ. Developmental Biology 260 226-244. (doi:10.1016/S0012-1606(03)00219-7) 
Chen J, Jette C, Kanki JP, Aster JC, Look AT \& Griffin JD 2007 NOTCH1-induced T-cell leukemia in transgenic zebrafish. Leukemia 21 462-471. (doi:10.1038/sj.leu. 2404546)

Croushore JA, Blasiole B, Riddle RC, Thisse C, Thisse B, Canfield VA, Robertson GP, Cheng KC \& Levenson R 2005 Ptena and ptenb genes play distinct roles in zebrafish embryogenesis. Developmental Dynamics 234 911-921. (doi:10.1002/dvdy.20576)

Dambly-Chaudiere C, Sapede D, Soubiran F, Decorde K, Gompel N \& Ghysen A 2003 The lateral line of zebrafish: a model system for the analysis of morphogenesis and neural development in vertebrates. Biology of the Cell 95 579-587. (doi:10.1016/j.biolcel.2003.10.005)

Dayyani F, Wang J, Yeh JR, Ahn EY, Tobey E, Zhang DE, Bernstein ID, Peterson RT \& Sweetser DA 2008 Loss of TLE1 and TLE4 from the del(9q) commonly deleted region in AML cooperates with AML1-ETO to affect myeloid cell proliferation and survival. Blood 111 4338-4347. (doi:10.1182/blood-2007-07-103291)

Doghman M, Karpova T, Rodrigues GA, Arhatte M, De Moura J, Cavalli LR, Virolle V, Barbry P, Zambetti GP, Figueiredo BC et al. 2007 Increased steroidogenic factor-1 dosage triggers adrenocortical cell proliferation and cancer. Molecular Endocrinology 21 2968-2987. (doi:10.1210/me.2007-0120)

Dovey M, White RM \& Zon LI 2009 Oncogenic NRAS cooperates with p53 loss to generate melanoma in zebrafish. Zebrafish 6 397-404. (doi:10.1089/zeb.2009.0606)

Doyon Y, McCammon JM, Miller JC, Faraji F, Ngo C, Katibah GE, Amora R, Hocking TD, Zhang L, Rebar EJ et al. 2008 Heritable targeted gene disruption in zebrafish using designed zinc-finger nucleases. Nature Biotechnology 26 702-708. (doi:10.1038/nbt1409)

Driever W, Solnica-Krezel L, Schier AF, Neuhauss SC, Malicki J, Stemple DL, Stainier DY, Zwartkruis F, Abdelilah S, Rangini Z et al. 1996 A genetic screen for mutations affecting embryogenesis in zebrafish. Development 123 37-46.

Elsalini OA \& Rohr KB 2003 Phenylthiourea disrupts thyroid function in developing zebrafish. Development Genes and Evolution 212 593-598. (doi:10.1007/s00427-002-0279-3)

Elsalini OA, von Gartzen J, Cramer M \& Rohr KB 2003 Zebrafish hhex, nk2.1a, and pax2.1 regulate thyroid growth and differentiation downstream of Nodal-dependent transcription factors. Developmental Biology 263 67-80. (doi:10.1016/S0012-1606(03)00436-6)

Faucherre A, Taylor GS, Overvoorde J, Dixon JE \& Hertog J 2008 Zebrafish pten genes have overlapping and nonredundant functions in tumorigenesis and embryonic development. Oncogene 27 1079-1086. (doi:10.1038/sj. onc.1210730)

Feitsma H, Kuiper RV, Korving J, Nijman IJ \& Cuppen E 2008 Zebrafish with mutations in mismatch repair genes develop neurofibromas and other tumors. Cancer Research 68 5059-5066. (doi:10.1158/0008-5472.CAN08-0019)
Feng H, Langenau DM, Madge JA, Quinkertz A, Gutierrez A, Neuberg DS, Kanki JP \& Look AT 2007 Heat-shock induction of T-cell lymphoma/leukaemia in conditional Cre/lox-regulated transgenic zebrafish. British Journal of Haematology 138 169-175. (doi:10.1111/j.1365-2141. 2007.06625.x)

Foley JE, Yeh JR, Maeder ML, Reyon D, Sander JD, Peterson RT \& Joung JK 2009 Rapid mutation of endogenous zebrafish genes using zinc finger nucleases made by oligomerized pool engineering (OPEN). PLoS ONE 4 e4348. (doi:10.1371/journal.pone.0004348)

Gallo VP \& Civinini A 2003 Survey of the adrenal homolog in teleosts. International Review of Cytology 230 89-187. (doi:10.1016/S0074-7696(03)30003-8)

Goessling W, North TE \& Zon LI 2007 Ultrasound biomicroscopy permits in vivo characterization of zebrafish liver tumors. Nature Methods 4 551-553. (doi:10. 1038/nmeth1059)

Goessling W, North TE, Lord AM, Ceol C, Lee S, Weidinger G, Bourque C, Strijbosch R, Haramis AP, Puder M et al. 2008 APC mutant zebrafish uncover a changing temporal requirement for wnt signaling in liver development. Developmental Biology 320 161-174. (doi:10.1016/j. ydbio.2008.05.526)

Golling G, Amsterdam A, Sun Z, Antonelli M, Maldonado E, Chen W, Burgess S, Haldi M, Artzt K, Farrington S et al. 2002 Insertional mutagenesis in zebrafish rapidly identifies genes essential for early vertebrate development. Nature Genetics 31 135-140. (doi:10.1038/ng896)

Haffter P \& Nusslein-Volhard C 1996 Large scale genetics in a small vertebrate, the zebrafish. International Journal of Developmental Biology 40 221-227.

Haffter P, Granato M, Brand M, Mullins MC, Hammerschmidt M, Kane DA, Odenthal J, van Eeden FJ, Jiang YJ, Heisenberg CP et al. 1996 The identification of genes with unique and essential functions in the development of the zebrafish, Danio rerio. Development 123 1-36.

Haldi M, Ton C, Seng WL \& McGrath P 2006 Human melanoma cells transplanted into zebrafish proliferate, migrate, produce melanin, form masses and stimulate angiogenesis in zebrafish. Angiogenesis 9 139-151. (doi:10.1007/s10456-006-9040-2)

Haramis AP, Hurlstone A, van der Velden Y, Begthel H, van den Born M, Offerhaus GJ \& Clevers HC 2006 Adenomatous polyposis coli-deficient zebrafish are susceptible to digestive tract neoplasia. EMBO Reports 7 444-449. (doi:10.1038/sj.embor.7400638)

Hogan BM, Hunter MP, Oates AC, Crowhurst MO, Hall NE, Heath JK, Prince VE \& Lieschke GJ 2004 Zebrafish gcm2 is required for gill filament budding from pharyngeal ectoderm. Developmental Biology 276 508-522. (doi:10. 1016/j.ydbio.2004.09.018)

Hsu HJ, Lin G \& Chung BC 2003 Parallel early development of zebrafish interrenal glands and pronephros: differential control by wt 1 and ff1b. Development 130 2107-2116. (doi:10.1242/dev.00427) 
Hurlstone AF, Haramis AP, Wienholds E, Begthel H, Korving J, Van Eeden F, Cuppen E, Zivkovic D, Plasterk RH \& Clevers H 2003 The Wnt/beta-catenin pathway regulates cardiac valve formation. Nature 425 633-637. (doi:10.1038/nature02028)

Jiang Z, Song J, Qi F, Xiao A, An X, Liu NA, Zhu Z, Zhang B \& Lin S 2008 Exdpf is a key regulator of exocrine pancreas development controlled by retinoic acid and ptf1a in zebrafish. PLoS Biology 6 e293. (doi:10.1371/ journal.pbio.0060293)

Ju B, Spitsbergen J, Eden CJ, Taylor MR \& Chen W 2009 Co-activation of hedgehog and AKT pathways promote tumorigenesis in zebrafish. Molecular Cancer 840. (doi:10.1186/1476-4598-8-40)

Kalev-Zylinska ML, Horsfield JA, Flores MV, Postlethwait JH, Vitas MR, Baas AM, Crosier PS \& Crosier KE 2002 Runx1 is required for zebrafish blood and vessel development and expression of a human RUNX1CBF2T1 transgene advances a model for studies of leukemogenesis. Development 129 2015-2030.

Kim AC, Reuter AL, Zubair M, Else T, Serecky K, Bingham NC, Lavery GG, Parker KL \& Hammer GD 2008 Targeted disruption of beta-catenin in Sf1-expressing cells impairs development and maintenance of the adrenal cortex. Development 135 2593-2602. (doi:10.1242/dev. 021493)

Lai K, Amsterdam A, Farrington S, Bronson RT, Hopkins N \& Lees JA 2009 Many ribosomal protein mutations are associated with growth impairment and tumor predisposition in zebrafish. Developmental Dynamics 238 76-85. (doi:10.1002/dvdy.21815)

Langenau DM, Traver D, Ferrando AA, Kutok JL, Aster JC, Kanki JP, Lin S, Prochownik E, Trede NS, Zon LI et al. 2003 Myc-induced T cell leukemia in transgenic zebrafish. Science 299 887-890. (doi:10.1126/science. 1080280)

Langenau DM, Feng H, Berghmans S, Kanki JP, Kutok JL \& Look AT 2005 Cre/lox-regulated transgenic zebrafish model with conditional myc-induced $\mathrm{T}$ cell acute lymphoblastic leukemia. PNAS 102 6068-6073. (doi:10. 1073/pnas.0408708102)

Langenau DM, Keefe MD, Storer NY, Guyon JR, Kutok JL, Le X, Goessling W, Neuberg DS, Kunkel LM \& Zon LI 2007 Effects of RAS on the genesis of embryonal rhabdomyosarcoma. Genes and Development 21 1382-1395. (doi:10.1101/gad.1545007)

Le X, Langenau DM, Keefe MD, Kutok JL, Neuberg DS \& Zon LI 2007 Heat shock-inducible Cre/Lox approaches to induce diverse types of tumors and hyperplasia in transgenic zebrafish. PNAS 104 9410-9415. (doi:10.1073/ pnas.0611302104)

Lee LM, Seftor EA, Bonde G, Cornell RA \& Hendrix MJ 2005 The fate of human malignant melanoma cells transplanted into zebrafish embryos: assessment of migration and cell division in the absence of tumor formation. Developmental Dynamics 233 1560-1570. (doi:10.1002/dvdy.20471)
Lee SL, Rouhi P, Dahl Jensen L, Zhang D, Ji H, Hauptmann G, Ingham P \& Cao Y 2009 Hypoxiainduced pathological angiogenesis mediates tumor cell dissemination, invasion, and metastasis in a zebrafish tumor model. PNAS 106 19485-19490. (doi:10.1073/ pnas.0909228106)

Lord AM, North TE \& Zon LI 2007 Prostaglandin $E_{2}$ : making more of your marrow. Cell Cycle 6 3054-3057. (doi:10.4161/cc.6.24.5129)

Maeder ML, Thibodeau-Beganny S, Osiak A, Wright DA, Anthony RM, Eichtinger M, Jiang T, Foley JE, Winfrey RJ, Townsend JA et al. 2008 Rapid "open-source" engineering of customized zinc-finger nucleases for highly efficient gene modification. Molecular Cell $\mathbf{3 1}$ 294-301. (doi:10.1016/j.molcel.2008.06.016)

Marques IJ, Weiss FU, Vlecken DH, Nitsche C, Bakkers J, Lagendijk AK, Partecke LI, Heidecke CD, Lerch MM \& Bagowski CP 2009 Metastatic behaviour of primary human tumours in a zebrafish xenotransplantation model. BMC Cancer 9 128. (doi:10.1186/1471-24079-128)

Meng X, Noyes MB, Zhu LJ, Lawson ND \& Wolfe SA 2008 Targeted gene inactivation in zebrafish using engineered zinc-finger nucleases. Nature Biotechnology 26 695-701. (doi:10.1038/nbt1398)

Michailidou C, Jones M, Walker P, Kamarashev J, Kelly A \& Hurlstone AF 2009 Dissecting the roles of Raf- and PI3Ksignalling pathways in melanoma formation and progression in a zebrafish model. Disease Models \& Mechanisms 2 399-411. (doi:10.1242/dmm.001149)

Milan DJ, Peterson TA, Ruskin JN, Peterson RT \& MacRae CA 2003 Drugs that induce repolarization abnormalities cause bradycardia in zebrafish. Circulation $\mathbf{1 0 7}$ 1355-1358. (doi:10.1161/01.CIR.0000061912.88753.87)

Mizgireuv IV \& Revskoy SY 2006 Transplantable tumor lines generated in clonal zebrafish. Cancer Research 66 3120-3125. (doi:10.1158/0008-5472.CAN-05-3800)

Mizgirev IV \& Revskoy S 2010 A new zebrafish model for experimental leukemia therapy. Cancer Biology \& Therapy 9 895-902. (doi:10.4161/cbt.9.11.11667)

Neumann JC, Dovey JS, Chandler GL, Carbajal L \& Amatruda JF 2009 Identification of a heritable model of testicular germ cell tumor in the zebrafish. Zebrafish 6 319-327. (doi:10.1089/zeb.2009.0613)

Nicoli S \& Presta M 2007 The zebrafish/tumor xenograft angiogenesis assay. Nature Protocols 2 2918-2923. (doi:10.1038/nprot.2007.412)

Nicoli S, Ribatti D, Cotelli F \& Presta M 2007 Mammalian tumor xenografts induce neovascularization in zebrafish embryos. Cancer Research 67 2927-2931. (doi:10.1158/ 0008-5472.CAN-06-4268)

North TE, Goessling W, Walkley CR, Lengerke C, Kopani KR, Lord AM, Weber GJ, Bowman TV, Jang IH, Grosser $\mathrm{T}$ et al. 2007 Prostaglandin $\mathrm{E}_{2}$ regulates vertebrate haematopoietic stem cell homeostasis. Nature 447 1007-1011. (doi:10.1038/nature05883) 
Ober EA, Field HA \& Stainier DY 2003 From endoderm formation to liver and pancreas development in zebrafish. Mechanisms of Development 120 5-18. (doi:10.1016/ S0925-4773(02)00327-1)

Okabe M \& Graham A 2004 The origin of the parathyroid gland. PNAS 101 17716-17719. (doi:10.1073/pnas. 0406116101)

Onnebo SM, Condron MM, McPhee DO, Lieschke GJ \& Ward AC 2005 Hematopoietic perturbation in zebrafish expressing a tel-jak2a fusion. Experimental Hematology 33 182-188. (doi:10.1016/j.exphem.2004.10.019)

Owens KN, Santos F, Roberts B, Linbo T, Coffin AB, Knisely AJ, Simon JA, Rubel EW \& Raible DW 2008 Identification of genetic and chemical modulators of zebrafish mechanosensory hair cell death. PLoS Genetics 4 e1000020. (doi:10.1371/journal.pgen.1000020)

Park EH, Chang HH, Lee KC, Kweon HS, Heo OS \& Ha KW 1993 High frequency of thyroid tumor induction by $N$-methyl- $N^{\prime}$-nitro- $N$-nitrosoguanidine in the hermaphroditic fish Rivulus marmoratus. Japanese Journal of Cancer Research 84 608-615.

Park SW, Davison JM, Rhee J, Hruban RH, Maitra A \& Leach SD 2008 Oncogenic KRAS induces progenitor cell expansion and malignant transformation in zebrafish exocrine pancreas. Gastroenterology 134 2080-2090. (doi:10.1053/j.gastro.2008.02.084)

Patton EE, Widlund HR, Kutok JL, Kopani KR, Amatruda JF, Murphey RD, Berghmans S, Mayhall EA, Traver D, Fletcher CD et al. 2005 BRAF mutations are sufficient to promote nevi formation and cooperate with p53 in the genesis of melanoma. Current Biology 15 249-254. (doi:10.1016/j.cub.2005.01.031)

Peterson RT, Shaw SY, Peterson TA, Milan DJ, Zhong TP, Schreiber SL, MacRae CA \& Fishman MC 2004 Chemical suppression of a genetic mutation in a zebrafish model of aortic coarctation. Nature Biotechnology 22 595-599. (doi:10.1038/nbt963)

Porteus MH \& Carroll D 2005 Gene targeting using zinc finger nucleases. Nature Biotechnology 23 967-973. (doi:10.1038/nbt1125)

Rhodes J, Amsterdam A, Sanda T, Moreau LA, McKenna K, Heinrichs S, Ganem NJ, Ho KW, Neuberg DS, Johnston A et al. 2009 Emi1 maintains genomic integrity during zebrafish embryogenesis and cooperates with p53 in tumor suppression. Molecular and Cellular Biology 29 5911-5922. (doi:10.1128/MCB.00558-09)

Rohr KB \& Concha ML 2000 Expression of nk2.1a during early development of the thyroid gland in zebrafish. Mechanisms of Development 95 267-270. (doi:10.1016/ S0925-4773(00)00345-2)

Rouhi P, Jensen LD, Cao Z, Hosaka K, Lanne T, Wahlberg E, Steffensen JF \& Cao Y 2010 Hypoxia-induced metastasis model in embryonic zebrafish. Nature Protocols 5 1911-1918. (doi:10.1038/nprot.2010.150)

Rozenblatt-Rosen O, Hughes CM, Nannepaga SJ, Shanmugam KS, Copeland TD, Guszczynski T, Resau JH \& Meyerson M 2005 The parafibromin tumor suppressor protein is part of a human Paf1 complex. Molecular and Cellular Biology 25 612-620. (doi:10.1128/MCB.25.2. 612-620.2005)

Sabaawy HE, Azuma M, Embree LJ, Tsai HJ, Starost MF \& Hickstein DD 2006 TEL-AML1 transgenic zebrafish model of precursor B cell acute lymphoblastic leukemia. PNAS 103 15166-15171. (doi:10.1073/pnas.0603349103)

Santoriello C, Gennaro E, Anelli V, Distel M, Kelly A, Koster RW, Hurlstone A \& Mione M 2010 Kita driven expression of oncogenic HRAS leads to early onset and highly penetrant melanoma in zebrafish. PLOS ONE 5 e15170. (doi:10.1371/journal.pone.0015170)

Shepard JL, Amatruda JF, Stern HM, Subramanian A, Finkelstein D, Ziai J, Finley KR, Pfaff KL, Hersey C, Zhou Y et al. 2005 A zebrafish bmyb mutation causes genome instability and increased cancer susceptibility. PNAS 102 13194-13199. (doi:10.1073/pnas.0506583102)

Shepard JL, Amatruda JF, Finkelstein D, Ziai J, Finley KR, Stern HM, Chiang K, Hersey C, Barut B, Freeman JL et al. 2007 A mutation in separase causes genome instability and increased susceptibility to epithelial cancer. Genes and Development 21 55-59. (doi:10.1101/ gad.1470407)

Shive HR, West RR, Embree LJ, Azuma M, Sood R, Liu P \& Hickstein DD 2010 brca2 in zebrafish ovarian development, spermatogenesis, and tumorigenesis. PNAS 107 19350-19355. (doi:10.1073/pnas.1011630107)

Sidi S, Sanda T, Kennedy RD, Hagen AT, Jette CA, Hoffmans R, Pascual J, Imamura S, Kishi S, Amatruda JF et al. 2008 Chk1 suppresses a caspase-2 apoptotic response to DNA damage that bypasses $\mathrm{p} 53, \mathrm{Bcl}-2$, and caspase-3. Cell 133 864-877. (doi:10.1016/j.cell. 2008.03.037)

Smith AC, Raimondi AR, Salthouse CD, Ignatius MS, Blackburn JS, Mizgirev IV, Storer NY, de Jong JL, Chen AT, Zhou Y et al. 2010 High-throughput cell transplantation establishes that tumor-initiating cells are abundant in zebrafish T-cell acute lymphoblastic leukemia. Blood 115 3296-3303. (doi:10.1182/blood-2009-10246488)

Spitsbergen JM, Tsai HW, Reddy A, Miller T, Arbogast D, Hendricks JD \& Bailey GS 2000a Neoplasia in zebrafish (Danio rerio) treated with 7,12-dimethylbenz[a]anthracene by two exposure routes at different developmental stages. Toxicologic Pathology 28 705-715. (doi:10.1177/ 019262330002800511)

Spitsbergen JM, Tsai HW, Reddy A, Miller T, Arbogast D, Hendricks JD \& Bailey GS $2000 b$ Neoplasia in zebrafish (Danio rerio) treated with $N$-methyl- $N^{\prime}$-nitro- $N$-nitrosoguanidine by three exposure routes at different developmental stages. Toxicologic Pathology 28 716-725. (doi:10.1177/019262330002800512)

Stanton MF 1965 Diethylnitrosamine-induced hepatic degeneration and neoplasia in the aquarium fish, Brachydanio rerio. Journal of the National Cancer Institute 34 117-130. 
Stoletov K, Montel V, Lester RD, Gonias SL \& Klemke R 2007 High-resolution imaging of the dynamic tumor cell vascular interface in transparent zebrafish. PNAS 104 17406-17411. (doi:10.1073/pnas.0703446104)

Stoletov K, Kato H, Zardouzian E, Kelber J, Yang J, Shattil S \& Klemke R 2010 Visualizing extravasation dynamics of metastatic tumor cells. Journal of Cell Science $\mathbf{1 2 3}$ 2332-2341. (doi:10.1242/jcs.069443)

Streisinger G, Walker C, Dower N, Knauber D \& Singer F 1981 Production of clones of homozygous diploid zebra fish (Brachydanio rerio). Nature 291 293-296. (doi:10. 1038/291293a0)

Tiso N, Moro E \& Argenton F 2009 Zebrafish pancreas development. Molecular and Cellular Endocrinology 312 24-30. (doi:10.1016/j.mce.2009.04.018)

To TT, Hahner S, Nica G, Rohr KB, Hammerschmidt M, Winkler C \& Allolio B 2007 Pituitary-interrenal interaction in zebrafish interrenal organ development. Molecular Endocrinology 21 472-485. (doi:10.1210/me. 2006-0216)

Topczewska JM, Postovit LM, Margaryan NV, Sam A, Hess AR, Wheaton WW, Nickoloff BJ, Topczewski J \& Hendrix MJ 2006 Embryonic and tumorigenic pathways converge via Nodal signaling: role in melanoma aggressiveness. Nature Medicine 12 925-932. (doi:10. 1038/nm1448)

Weinstein BM, Stemple DL, Driever W \& Fishman MC 1995 Gridlock, a localized heritable vascular patterning defect in the zebrafish. Nature Medicine 1 1143-1147. (doi:10. 1038/nm1195-1143)

Wendl T, Lun K, Mione M, Favor J, Brand M, Wilson SW \& Rohr KB 2002 Pax2.1 is required for the development of thyroid follicles in zebrafish. Development 129 3751-3760.

Wendl T, Adzic D, Schoenebeck JJ, Scholpp S, Brand M, Yelon D \& Rohr KB 2007 Early developmental specification of the thyroid gland depends on hanexpressing surrounding tissue and on FGF signals. Development 134 2871-2879. (doi:10.1242/dev.02872)

White RM, Sessa A, Burke C, Bowman T, LeBlanc J, Ceol C, Bourque C, Dovey M, Goessling W, Burns CE et al. 2008 Transparent adult zebrafish as a tool for in vivo transplantation analysis. Cell Stem Cell 2 183-189. (doi:10.1016/j.stem.2007.11.002)

White RM, Cech J, Ratanasirintrawoot S, Lin CY, Rahl PB, Burke CJ, Langdon E, Tomlinson ML, Mosher J,
Kaufman C et al. 2011 DHODH modulates transcriptional elongation in the neural crest and melanoma. Nature 471 518-522. (doi:10.1038/nature09882)

Wienholds E, Schulte-Merker S, Walderich B \& Plasterk RH 2002 Target-selected inactivation of the zebrafish rag1 gene. Science 297 99-102. (doi:10.1126/science.1071762)

Yang HW, Kutok JL, Lee NH, Piao HY, Fletcher CD, Kanki JP \& Look AT 2004 Targeted expression of human MYCN selectively causes pancreatic neuroendocrine tumors in transgenic zebrafish. Cancer Research 64 7256-7262. (doi:10.1158/0008-5472.CAN-04-0931)

Yee NS, Yusuff S \& Pack M 2001 Zebrafish pdx1 morphant displays defects in pancreas development and digestive organ chirality, and potentially identifies a multipotent pancreas progenitor cell. Genesis 30 137-140. (doi:10. 1002/gene.1049)

Yee NS, Zhou W \& Liang IC 2011 Transient receptor potential ion channel Trpm7 regulates exocrine pancreatic epithelial proliferation by $\mathrm{Mg}^{2+}$-sensitive Socs $3 \mathrm{a}$ signaling in development and cancer. Disease Models \& Mechanisms 4 240-254. (doi:10.1242/dmm.004564)

Yeh JR, Munson KM, Chao YL, Peterson QP, Macrae CA \& Peterson RT 2008 AML1-ETO reprograms hematopoietic cell fate by downregulating scl expression. Development 135 401-410. (doi:10.1242/dev.008904)

Yeh JR, Munson KM, Elagib KE, Goldfarb AN, Sweetser DA \& Peterson RT 2009 Discovering chemical modifiers of oncogene-regulated hematopoietic differentiation. Nature Chemical Biology 5 236-243. (doi:10.1038/ nchembio.147)

Zhang G, Hoersch S, Amsterdam A, Whittaker CA, Lees JA \& Hopkins N 2010 Highly aneuploid zebrafish malignant peripheral nerve sheath tumors have genetic alterations similar to human cancers. PNAS 107 16940-16945. (doi:10.1073/pnas.1011548107)

Zhuravleva J, Paggetti J, Martin L, Hammann A, Solary E, Bastie JN \& Delva L 2008 MOZ/TIF2-induced acute myeloid leukaemia in transgenic fish. British Journal of Haematology 143 378-382. (doi:10.1111/j.1365-2141. 2008.07362.x)

Received in final form 20 May 2011

Accepted 31 May 2011

Made available online as an Accepted Preprint 1 June 2011 